\title{
Overconfidence and stock returns: a behavioural perspective
}

\section{Dimitrios Kourtidis*}

Kavala Institute of Technology,

Department of Accounting and Finance,

Kavala, Agios Loukas 65404, Greece

Email: dimitrios.kourtidis@gmail.com

${ }^{*}$ Corresponding author

\section{Željko Šević}

Faculty of Business and Management,

University of Wales TSD,

Swansea, SA1 6HD, UK

Email: zeljko.sevic@yahoo.co.uk

\section{Prodromos Chatzoglou}

Democritus University of Thrace,

Department of Production and Management Engineering,

Xanthi 67100, Greece

Email: pchatzog@pme.duth.gr

\begin{abstract}
This study attempts to group investors (individuals and professionals) into different segments based on their level of overconfidence (as a psychological bias) and, then, to examine whether, and to what extent, specific personality trait drive investors' trading behaviour. This study performing a cluster analysis, and using a representative survey of 345 investors in Greece, identified two main segments of investors: Overconfident investors and Underconfident investors. A comparative analysis between these two segments identified some differences in the trading behaviour of investors, depending on the segment they belong to. Moreover, a statistical association between investors' clusters and various demographic, socioeconomic characteristics and trading behaviour is also found.
\end{abstract}

Keywords: overconfidence; trading behaviour; psychological bias; behavioural finance.

Reference to this paper should be made as follows: Kourtidis, D., Šević, Ž. and Chatzoglou, P. (2015) 'Overconfidence and stock returns: a behavioural perspective', Int. J. Behavioural Accounting and Finance, Vol. 5, No. 1, pp.57-81.

Biographical notes: Kourtidis Dimitrios received his $\mathrm{PhD}$ from Glasgow Caledonian University in 2012. His PhD dissertation focused in finance and investigated investors' trading activity from a behavioural perspective. $\mathrm{He}$ received an MSc in 'Finance and Financial Information Systems' from the University of Greenwich, London, UK, 2006 and an Undergraduate certificate 
in 'Accounting' from Serres Institute of Technology, Greece, 2004. He teaches finance and accounting courses (Postgraduate and Undergraduate) in Department of Finance and Accounting in Kavala Institute of Technology, Greece.

Željko Šević is a past Dean of the Faculty of Business and Management and Professor of Accounting, Finance and Public Policy at the University of Wales TSD. Previously he was with the Glasgow Caledonian University, University of Greenwich, and University of Dundee, and has held a number of visiting positions in Australia, Japan, and the US. His research interests are in management accounting, economics of financial markets and applied public policy.

Prodromos D. Chatzoglou is a Professor of MIS and Business Decisions in the Department of Production and Management Engineering (Democritus University of Thrace, Xanthi, Greece). He received a BA (Economics) from Graduate Industrial School, Thessaloniki, Greece, an MSc (Management Sciences) and a $\mathrm{PhD}$ (Information Engineering), both from UMIST, Manchester, UK. His research interests include Knowledge Management, IS Economics, Strategic Management and Business Performance. He has published in Decision Science, Information Systems Journal, European Journal of Information Systems, International Journal of Medical Informatics, etc. He serves as a reviewer and member of the scientific committee of many international journals.

\section{Introduction}

Traditional finance literature assumes that investors make rational decision and that they attempt to maximise the expected returns (Siegel, 2007). The foundation of traditional finance during the 1960s was lying on the modern portfolio theory-MPT (Markowitz, 1952), capital asset pricing model (CAPM) (Fama and Kenneth, 2004) and the efficient market hypothesis-EMH (Lo and MacKinley, 1999). These traditional theories can be evaluated as normative theories that seek to explain or predict what would happen under theoretical constraints (Rawls, 1971). However, the traditional financial theories have been criticised in terms of their explanatory power and the validity of their assumptions (Takahashi and Terano, 2003).

Behavioural finance is based on the alternative notion that investors are subject to behavioural biases and, therefore, their financial decisions can be less than fully rational (Byrne and Brooks, 2008). According to the theory of behavioural finance the average investor is not fully rational and there is irrationality of human decision-making in financial markets (Barberis and Thaler, 2005; Bazerman, 1998; Hogarth, 1987; Russo and Schoemaker, 1991; Firat and Fettahoglou, 2011).

There are studies that have shown that investors do not act in a rational way in some of their investment decisions and, thus, most financial models fail to explain their real investment behaviour (Kiyilar and Acar, 2009; Shiller, 2002; Chang, 2008). Nagy and Obenberger (1994), examining factors influencing investor behaviour, suggested that although classical wealth-maximisation criteria are important to investors, they use diverse criteria when choosing stocks. 
Kahneman and Tversky (1979) believe that the study of psychology and other social science theories can shed much light on the efficiency of financial markets, as well as explain many stock market anomalies, market bubbles, and crashes (Shiller, 2000). Behavioural finance challenges the assumption that investors are perfectly rational at all times and suggests that, in fact, they tend to leave from optimal financial decisionmaking in a predictable, systematic way (Tourani-Rad and Kirkby, 2005).

The behavioural finance literature has developed a number of behavioural concepts that explain investment behaviour. This paper selects and reviews overconfidence bias to classify investors into profiles and, then, to compare their level of overconfidence with their trading behaviour. More specifically, this study examines whether different level of overconfidence leads to differences in the investment behaviour and trading performance among various groups of investors with different profiles. The research framework that is suggested by this study will, hopefully, help investors understand how overconfidence affects their investment decisions.

The results expand investors' knowledge about financial decision-making process and trading behaviour and, also, highlight the trading behaviour differences between individual and professional groups. To the best of our knowledge, there is neither a study in Greece that directly compares individual and professional investors' trading behaviour. Moreover, this study, in spite of the fact that it was conducted on the Greek market, can help people understand what happens in investors' behaviour in other similar (small) capital markets in all over the world. Thus, the main research gap that this research will attempt to fill is the link between Overconfidence and stock returns in small capital markets.

The research population included Greek investors with at least one transaction in 2007 at the ASE (Athens stock exchange). The general index of the ASE was below 2000 units before 1999 while it was risen up to 6500 units during 1998-2000, and has fallen dramatically down to 1500 units in 2003. During the 'boom' period of the ASE (1998-2000) a large proportion of the adult population in Greece (representing probably more than half of the Greek households) changed their traditional investment preferences (saving their money in bank accounts) and started regularly trading in the ASE. There were two main reasons for that: the significant decrease in the interest rates paid by banks for saving accounts due to the very low for the Greece's case, inflation rate and the unusual and abnormal increase of the stock prices of all trading companies. It was almost impossible for someone to have less than $35 \%$ profits, let alone lose money, during this period. The end of this period (2003) observed a dramatic decrease in the number of active accounts; especially those belonged to individuals who, in most cases, did not manage to salvage anything. Since then, very few, brave, individuals continue to irregularly invest in ASE in relatively low volume. Therefore, it can be easily argued that the sample of this research holds all the main characteristics of the population of individual investor trading in ASE. Moreover, the threat of social unrest is growing across emerging markets, as the recent financial crisis inflates unemployment and economic pain, inducing instability that threatens investors leading, for example, to the mass exodus of funds that followed the intervention and provision of funding to Greece into the IMF (international monetary fund) in April 2010. 


\section{Literature review-overconfidence}

It is possible that investment decisions can be affected by personality traits such as overconfidence (DeLamater and Myers, 2011; Gervais and Odean, 2001). Overconfidence causes investors to be too certain about their own abilities, unreasonably optimistic and unable to give sufficient weight to the opinion of others (Nofsinger, 2007; DellaVigna, 2009; Johnson and Fowler, 2009; Ben-David et al., 2007). People typically state that they are above average, when assessing their position in a distribution of peers, although, of course, only half can be (Svenson, 1981). Psychological studies document that overconfidence affects our behaviour in many ways (Lichtenstein et al., 1982; Griffin and Tversky, 1992). For example, in some quizzes people rate their answers as 99\% reliable but are wrong $40 \%$ of the time (DeLamater and Myers, 2011).

People who are overconfident overestimating their knowledge and their judgements (Campbell et al., 2004; Griffin and Tversky, 1992). Cheng (2007) claims that overconfidence is a common characteristic found in humans, which depicts that they overestimate their ability, the accuracy of the knowledge they have, their chances for success and the probability that positive outcomes will be gained.

There are four aspects of overconfidence: miscalibration (Glaser and Weber, 2010), better than average effect (Hilton et al., 2011; Larrick et al., 2007), illusion of control (Presson and Benassi, 1996) and unrealistic optimism (Weinstein, 1980). Miscalibration is the tendency to overestimate the accuracy of ones' own information (Biais et al., 2005; Philip, 2007; Teigen and Jorgensen, 2005). The miscalibration is evaluated by asking for upper and lower bounds of $90 \%$ confidence intervals for the return on a stock in the future (Hilton, 2001).

Gender and age are factors that influence people's overconfidence (Tyynela and Perttunen, 2003). The literature suggests that men are apparently further predisposed to overconfidence than women (Lundeberg et al., 1994; Barber and Odean, 2001; Niederle and Vesterlund, 2007). Barber and Odean (2001) found that men trade $45 \%$ more actively than women. In the same line, Hair et al. (1998) have documented that men are more overconfident than women, while Shu et al. (2004) have shown that, even though men trade further excessively than women, their performance is not dramatically lower than this of women. In addition, Barber and Odean (2000) have argued that men's higher overconfidence in their judgement leads them to trade more and to take riskier positions than women. However, other studies have found no difference in overconfidence between men and women (Lundeberg et al., 2000; Deaves et al., 2003; Biais et al., 2005). Moreover, socioeconomic factors, such as the educational background, influence the level of humans' overconfidence. For example, Bhandari and Deaves (2006) claim that investors with higher education background have higher level of overconfidence than those who have lower education level.

Current research indicates that the participation of overconfident traders in the market leads to higher trading frequency (Odean, 1999; Barber and Odean, 2000, 2001; Pompian, 2006; Graham et al., 2009; Grinblatt and Keloharju, 2009). Glaser and Weber (2005) and Grinblatt and Keloharju (2009) suggest that overconfident traders trade more often. Trinugroho and Sembel (2011) claim that overconfident investors believe that they have specialised knowledge and abilities about stock market investments and this is the reason they trade more often. Also, they report that individual investors, whose trading responds stronger to past returns, trade often in general. Glaser and Weber (2007), using 
data of individual online investors, found that high levels of overconfidence are related to high trading frequency.

Additionally, the literature shows that overconfidence increases trading volume (De Bondt and Thaler, 1995; Odean, 1998a, 1998b, 1999; Gervais and Odean, 2001; Caballe and Sakovics, 2003; Barberis and Thaler, 2003; Glaser and Weber, 2007; Dow and Gorton, 1997; Prosad et al., 2013; Siwal, 2011).

Gervais and Odean (2001) agree that overconfident investors trade too aggressively and this results in increased trading volume. Several other studies have also suggested that overconfidence leads to greater trading activity (Daniel et al., 2001; Hirshleifer and Luo, 2001; Scheinkman and Xiong, 2003; Trinugroho and Sembel, 2011; Kim and Nofsinger, 2007; Shefrin, 2002; Barber and Odean, 2001, 2002; Pompian, 2006; Graham et al., 2009; Linnainmaa, 2011).

Research has shown that overconfidence leads not only to increased trading activity but also to increased probabilities of taking wrong decisions (e.g., buying the wrong stocks). Several studies have found that higher overconfidence generally leads to poorer trading performance (Philip, 2007; Kirchler and Maciejovsky, 2002; Biais et al., 2005; Shefrin, 2002; Fenton-O'Creevy et al., 2003). Odean (1999) also reported that individual investors' performance is reduced when they trade more often. Odean (1998b) shows that an overconfident individual trader makes biased judgements that may lead to lower returns.

On the other hand, De Long et al. (1990) and Wang (2001) have shown that overconfident investors earn higher returns than less confident investors. Along the same lines, Daniel et al. (1998) claimed that, despite the average impact of overconfidence on financial markets being harmful, sometimes it may generate returns in excess of rational investors.

Overconfident investors believe that they can achieve high returns, trade often and underestimate the associated risks (Hirshleifer and Luo, 2001; Wang, 2001; Pompian, 2006; Russo and Shoemaker, 1992; Odean, 1998b; De Long et al., 1991; Wang, 2001). Additionally, Kahneman and Riepe (1998) claim that overconfidence causes people to overestimate their knowledge and underestimate the risks. As a result of underestimating risk, overconfident investors hold risky assets. Barber and Odean (2001) and Chuang and Lee (2006) support the previous claim also arguing that individual overconfident investors underestimate risk and trade more in riskier securities.

Glaser et al. (2013) stress that the way researchers measure overconfidence drives the results in the direction of documenting overconfidence when there is in fact none. These studies show that overconfidence can easily be explained by different degrees of knowledge of agents plus a random error in predictions (Glaser et al., 2013).

On an empirical basis, since psychological and behavioural research reveals that overconfidence and optimism are closely related and are likely to appear jointly (Taylor and Brown, 1988), an optimistic person will tend to be overconfident and vice-versa. Therefore, proxies for optimism and overconfidence do not need, ordinarily, to capture each bias separately (Fabre and Francois-Heude, 2009).

Hoelzl and Rustichini (2005) claim that choice behaviour changes from overconfidence to underconfidence when the task changes from easy and familiar to nonfamiliar. Kruger (1999) also finds that people tend to be underconfident and not overconfident when the task is perceived as difficult. 


\section{Research theoretical discussions}

\subsection{Associations development}

This study attempts to group investors (individuals and professionals) into different segments based on their overconfidence level and, then, to check whether, as well as how, this bias drive their investment behaviour. The behavioural finance literature associates overconfidence with investment behaviour. This study is trying to confirm the association between these factors, also taking into account differences in the investors' profiles (high or low confidence) and their trading behaviour. Initially, the following Associations are proposed (Table 1).

Table 1 Associations

\begin{tabular}{|c|c|c|}
\hline Number & Associations & Supporting literature \\
\hline 1 & $\begin{array}{l}\text { Overconfidence positively } \\
\text { affects trading volume }\end{array}$ & $\begin{array}{l}\text { De Bondt and Thaler (1995), Odean (1998, 1999), } \\
\text { Glaser and Weber (2007), Deaves et al. (2003), } \\
\text { Gervais and Odean (2001), Dow and Gorton (1997), } \\
\text { Statman et al. (2006), Statman and Thorely (1999), } \\
\text { Prosad et al. (2013) and Siwal (2011) }\end{array}$ \\
\hline 2 & $\begin{array}{l}\text { Overconfidence positively } \\
\text { affects trading frequency }\end{array}$ & $\begin{array}{l}\text { Grinblatt and Keloharju (2009), Alemanni and } \\
\text { Franzosi (2006), Deaves et al. (2003), Glaser and } \\
\text { Weber (2007), Graham et al. (2009), Pompian (2006), } \\
\text { Trinugroho and Sembel (2011) }\end{array}$ \\
\hline 3 & $\begin{array}{l}\text { Overconfidence positively } \\
\text { affect trading performance }\end{array}$ & De Long et al. (1990) and Wang (2001) \\
\hline 4 & $\begin{array}{l}\text { Investment experience } \\
\text { positively affects } \\
\text { overconfidence }\end{array}$ & $\begin{array}{l}\text { Gervais and Odean (2001), Locke and Mann (2001), } \\
\text { Menkhoff et al. (2006), Philip (2007), Ekholm and } \\
\text { Pasternack (2008), Frascara (1999), Maciejovsky and } \\
\text { Kirchler (2003), Glaser et al. (2003), Griffin and } \\
\text { Tversky (1992) and Obernarcher and Osler (2008) }\end{array}$ \\
\hline 5 & $\begin{array}{l}\text { Men are more overconfident } \\
\text { than women }\end{array}$ & Lundeberg et al. (1994) and Barber and Odean (2001) \\
\hline
\end{tabular}

\subsection{Questionnaire design}

The questionnaire was delivered to the target group face-to-face, to allow researcher discuss with participants the main aims of the research and provide them with all necessary explanations to eliminate possible mistakes in the understanding and completion of the questionnaires. The items that have been set to define the constructs derived from an extensive literature review and checked for their validity level. The measures utilised to assess the constructs in the study have been adopted by previous studies. Overconfidence is measured by (the facet of better than average effect) seven items (five-point Likert scale) that have been adapted from Wood and Zaichkowsky (2004). The second section includes questions about participants' stock transactions (in their private portfolio). There are six questions included, collecting information about their portfolio value, stock volume, stock returns, profitable transactions, and frequency of stock transactions. Additionally, ten questions focus on information about people's 
investing behaviour, such as types of stocks held and sources of investment information. Moreover, 12 demographic and socioeconomic items are included in this section.

To ensure that the items were clearly interpreted in the Greek language, backtranslation technique was utilised (Geisinger, 2003). An extensive pretesting with professional and individual investors took place in an attempt to improve the format of the questions. The pretest-sample included 27 investors who carefully read the questionnaires. From those, 10 were professional investors from big investment companies in Athens, 10 more were individual investors and seven were academics, experts in the financial investments field. The purpose of this process was to ensure the face and content validity of the instrument. To increase the response rate the questionnaire consists of closed (mainly multiple choice) questions because it is easier for the respondents to answer them.

All the necessary statistical tests have been performed to test the reliability and construct validity of the research instrument, such as Cronbach alpha, Total Variance Extracted (TVE) and KMO (Kaiser-Meyer-Olkin). The Cronbach alpha statistic has been used to determine the degree of consistency among the measurements of each construct. Cronbach alpha values range from 0 to 1 , while the accepted values are $\sim 0.6$ (Marković and Raspor, 2010). KMO is an index which measures the appropriateness of factor analysis (measuring the sampling adequacy). High values (between 0.5 and 1.0) indicate that factor analysis is appropriate and can be used to analyse the specific dataset. Total Variance Extracted assesses the amount of variance that is explained by an underlying factor in relation to the amount of variance due to measurement error (Hatcher, 1994).

Each construct of the survey exceeded the acceptable level (0.6) of Cronbach alpha (Marković and Raspor, 2010) and (0.5) of Kaiser-Meyer-Olkin (KMO) (Zikmund, 2003). Further TVE exceeds the acceptable level (50\%) (Cummins and Lau, 2005) (Table 2). In most cases, factor loadings exceeded the proposed 0.5 cut-off value, proposed by Straub (1989) and the 0.6 value proposed by Hair et al. (1989).

Table 2 Questionnaire design

\begin{tabular}{lllccc}
\hline Construct & Supporting literature & Items & KMO & Cronb. alpha \\
\hline Overconfidence & & Wood and & 7 & 0.817 & 0.801 \\
& Zaichkowsky (2004) & & & \\
Stock transactions & Volume & $\begin{array}{l}\text { Some of them have } \\
\text { been adapted from }\end{array}$ & 2 & 0.508 & 0.617 \\
& Frequency & Wood and & 0.529 & 0.703 \\
& Performance & Zaichkowsky (2004) & 2 & 0.510 & 0.631 \\
& & & & \\
& and Keller and & & & \\
\hline
\end{tabular}

The research population includes Greek investors with at least one transaction in 2007 in the ASE, including individuals (who trade in stocks and other securities for their personal portfolios) from all over the country (who do not have any direct or indirect relationship with any ASE company and who hold the same amount and quality of information about the companies as any other individual investor), but also professional investors (portfolio analysts as well as stockbrokers that have personal portfolios), who work in various investment companies located in all over the country (in order to achieve the maximum geographical distribution). 
Two hundred professional investors from 80 investment companies and 400 individual investors were contacted face to face. The individual investors who positively responded (through face to face contact) were 263 while the professional investors that successfully responded to the questionnaire were 83 .

Furthermore, although 160 investment companies received an email asking them to participate in this research, only nine of them responded positively despite the fact that a reminder was sent a month later (response rate for questionnaires sent out via email $=5.6 \%$ ). It should be also stressed that the Greek Association of Investment Companies accepted to send the questionnaire via email to 160 investment companies (its members) without actually getting any completed questionnaire back.

In an attempt to increase the number of investment companies participating in this research, it was decided to follow a different approach. A phone call was made to all the 151 investment companies that did not respond to the initial invitation. As a result, 67 people (from 42 companies) accepted to consider our request. Then, 67 questionnaires were posted (the envelope also included a second prepaid stamped envelope). The private investors were mainly located to North Greece, while the professional investors came from all over the country (mainly from Athens and Thessaloniki). In a few weeks, 18 of them were returned completed (response rate for posted questionnaires $=26.8 \%$ ).

The total number of the questionnaires returned was 373 . However, 28 questionnaires (individuals) were discarded since some questions had been left unanswered. Thus, the total number of valid questionnaires was 345. Of these, 200 and 35 questionnaires were filled from individuals (66\% response) and 110 questionnaires were filled from professionals ( $25 \%$ response).

\section{Analyses of results}

The objective of this study is to analyse the dataset performing descriptive and cluster analysis. Descriptive statistics were utilised to assess the characteristics of the overall sample. Then, cluster analysis was used to classify investors based on a set of specific criteria. The findings are in accordance with other studies (Sharma et al., 2006; Shapira and Venezia, 2001; De Long et al., 1990; Wang, 2001; Flynn and Ames, 2006; Biais et al., 2005; Shive, 2010; Garvey and Murphy, 2004; Putz and Ruenzi, 2008).

\subsection{Cluster analysis-two cluster solution}

Cluster analysis examines whether respondents scored similarly on a set of variables and seeks to identify a set of groups with the greatest possible distinction (Keller and Siergist, 2006). This study used $K$-means cluster analysis because this method is appropriate (unlike hierarchical clustering) for large datasets $(N>250)$. A range $(2-5)$ of clusters was tested and the greatest distinctiveness (with the appropriate significance) among the groups was provided by a 2-cluster solution: Overconfident investors, with high degree of overconfidence, and Underconfident investors, with low degree of overconfidence (Table 3). ANOVA has shown a statistically significant difference $(P<0.05)$ between the two clusters overconfidence construct (Table 3 ). Cross-tabulations between clusters for several demographics and trading characteristics were also run. As it is probably expected, it was found that investors with different profiles differ as far as their attitude 
toward stock trading is concerned. A detailed discussion of the findings from these analyses is provided in the next sections.

Table 3 Psychological biases and personality traits

\begin{tabular}{lccccccc}
\hline & \multicolumn{2}{c}{ Average } & \multicolumn{3}{c}{ Overconfident } & \multicolumn{3}{c}{ Underconfident } \\
\cline { 2 - 8 } & Means & St.D. & Means & St.D. & Means & St.D. & Sig. \\
\hline Overconfidence & 24.00 & 5.12 & 27.98 & 2.82 & 19.51 & 2.94 & 0.000 \\
\hline
\end{tabular}

\subsection{Overall sample analysis}

According to Table 4, the sample consists mainly of individual investors (68\%) but, also, from a significant number of professional investors $(32 \%)$. The majority of the respondents are male $(83 \%)$ and relatively young ( $61 \%$ of them are $<45$ years old). Their educational level is high, as $73 \%$ of them hold at least a bachelor degree (while some of them also hold a Master's degree). As far as the income level of the respondents is concerned, the median is Euro 30,000.

Table 4 Demographic and socioeconomic profile of clusters

\begin{tabular}{|c|c|c|c|c|}
\hline & Average (\%) & Overconfident $(\%)$ & Underconfident (\%) & Sig. \\
\hline Gender & & & & 0.000 \\
\hline Male & 83 & 91 & 75 & \\
\hline Female & 17 & 9 & 25 & \\
\hline Age & & & & 0.163 \\
\hline $25-35$ & 29 & 28 & 30 & \\
\hline $36-45$ & 33 & 36 & 29 & \\
\hline $46-55$ & 24 & 25 & 22 & \\
\hline $56-65$ & 12 & 8 & 16 & \\
\hline$>65$ & 3 & 3 & 3 & \\
\hline Educational level & & & & 0.000 \\
\hline High-school & 27 & 21 & 35 & \\
\hline University & 48 & 45 & 50 & \\
\hline Master & 25 & 34 & 15 & \\
\hline Income level & & & & 0.000 \\
\hline$<15,000$ & 9 & 7 & 12 & \\
\hline $15,000-30,000$ & 41 & 35 & 48 & \\
\hline $30,000-50,000$ & 28 & 27 & 29 & \\
\hline $50,000-100,000$ & 19 & 26 & 11 & \\
\hline$>100,000$ & 3 & 5 & 0 & \\
\hline Type & & & & 0.000 \\
\hline Professionals & 32 & 48 & 15 & \\
\hline Individuals & 68 & 52 & 85 & \\
\hline
\end{tabular}


Respondents reported that their average portfolio value (Table 5) was about Euro 69,500, while each stock transaction was on average about Euro 9000. The maximum portfolio value was much higher than the median, something that is explained by the fact that some of the people included in the sample are professionals in executive positions or individuals with high income (Table 4). Regarding their stock trading performance, they claim that their average stock return is $\sim 14 \%$, while their profitable stock transactions are only $\sim 56 \%$ of the total number of transactions. The average of stock returns of the sample is $13 \%$, while the earning stock transactions are only $56 \%$.

Table 6 presents the trading characteristics of the respondents. It seems that they have a rather good investment experience ( $49 \%$ of them have more than 10 years of investment experience, while only $17 \%$ have $<5$ years of investment experience). Also, they check stock prices quite often ( $62 \%$ of them check stock prices daily), but they rarely trade (only $45 \%$ of them make at least one transaction monthly).

Table 5 Basic trading patterns

\begin{tabular}{lcccc}
\hline & Average & Overconfident & Underconfident & \\
\cline { 2 - 4 } & Means & Means & Means & Sig. \\
\hline Portfolio value & 69,411 euro & 102,254 euro & 32,311 euro & 0.000 \\
Stock volume & 8916 euro & 11,216 euro & 6318 euro & 0.017 \\
Stock returns & $14.08 \%$ & $17.81 \%$ & $8.08 \%$ & 0.014 \\
Profitable stock & $55.77 \%$ & $59.58 \%$ & $51.47 \%$ & 0.001 \\
transactions & & & & \\
\hline
\end{tabular}

Table 6 Trading pattern of clusters

\begin{tabular}{lcccc}
\hline & Average (\%) & Overconfident (\%) & Underconfident $(\%)$ & Sig. \\
\hline Years of investment experience & 17 & 11 & 24 & 0.000 \\
$<5$ years & 34 & 22 & 46 & \\
$5-10$ years & 49 & 67 & 30 & 0.000 \\
$>10$ years & & & & \\
Times checked stock prices & 62 & 80 & 41 & \\
Daily & 17 & 9 & 28 & \\
Weekly & 2 & 2 & 13 & \\
Fortnightly & 10 & 7 & 16 & \\
Monthly & 9 & 2 & & \\
Quarterly & & & 5 & \\
Frequency of stock & & 18 & 4 & \\
transactions & 12 & 12 & 5 & \\
Daily & 8 & 9 & 14 & \\
Weekly & 7 & 22 & 12 & \\
Fortnightly & 18 & 16 & 60 & \\
Monthly & 14 & 23 & & \\
Quarterly & 41 & & & \\
Semi-annually & & & & \\
\hline
\end{tabular}


Table 6 Trading pattern of clusters (continued)

\begin{tabular}{|c|c|c|c|c|}
\hline & Average (\%) & Overconfident $(\%)$ & Underconfident (\%) & Sig. \\
\hline \multicolumn{5}{|l|}{ Investment horizon } \\
\hline Long term & 56 & 53 & 59 & 0.196 \\
\hline Medium term & 31 & 32 & 30 & 0.616 \\
\hline Short term & 13 & 15 & 11 & 0.201 \\
\hline \multicolumn{5}{|l|}{ Investment policy* } \\
\hline Stop loss & 20 & 20 & 20 & 0.9722 \\
\hline Max profit & 17 & 23 & 10 & 0.002 \\
\hline Target price & 16 & 23 & 7 & 0.000 \\
\hline Wait and see & 61 & 53 & 70 & 0.001 \\
\hline \multicolumn{5}{|l|}{ Investment information* } \\
\hline TV news & 37 & 40 & 33 & 0.173 \\
\hline Newspaper & 40 & 39 & 41 & 0.713 \\
\hline Balance Sheet & 34 & 51 & 14 & 0.000 \\
\hline $\begin{array}{l}\text { Fundamental analysis and } \\
\text { technical analysis }\end{array}$ & 36 & 55 & 15 & 0.000 \\
\hline Financial announcements & 34 & 41 & 27 & 0.005 \\
\hline Internet & 28 & 53 & 25 & 0.005 \\
\hline Financial analysts & 19 & 15 & 29 & 0.005 \\
\hline Friends & 12 & 7 & 19 & 0.001 \\
\hline Relatives & 4 & 3 & 6 & 0.301 \\
\hline Roumors & 12 & 11 & 14 & 0.452 \\
\hline Investment decision making & & & & 0.001 \\
\hline Athens stock exchange & 30 & 32 & 37 & \\
\hline Stock prospects & 19 & 24 & 20 & \\
\hline $\begin{array}{l}\text { Personal/psychological } \\
\text { reasons }\end{array}$ & 18 & 5 & 3 & \\
\hline
\end{tabular}

*The respondents could choose more than one answer.

Moreover, respondents were asked to describe their portfolio allocation; $56 \%$ of their portfolio is invested in long term investments, $13 \%$ in short term investments, while the remaining $31 \%$ in medium term investments. This is in line with the findings presented in the previous paragraph (concerning the trading frequency). It is not surprising, therefore, that it is found that the majority $(61 \%)$ of investors do not have a clear investment policy when they buy stocks. Only $20 \%$ of the participants follow a stop loss policy, $17 \%$ prefer a max profit policy and $16 \%$ adopt a target price policy.

It is also worth mentioning that when respondents were asked to define the major factor that significantly influences their investment decisions, they reported that the most important factors are the negative climate in the Athens stock exchange $(30 \%)$, the stock prospects (19\%) and various personal/psychological reasons (18\%). Further, respondents revealed that the most important information sources they are using during 
their decision making process are newspapers, TV news, fundamental and technical analyses (Table 7).

Table 7 Confirmatory factor analysis, investors' sample $N=345$

\begin{tabular}{lccccc}
\hline Constructs & CMIN/DF & CFI & GFI & TLI & RMR \\
\hline Overconfidence & 2.956 & 0.994 & 0.996 & 0.970 & 0.016 \\
Stock trading frequency & 0.962 & 0.997 & 0.992 & 0.967 & 0.038 \\
Stock trading volume & 1.314 & 0.991 & 0.993 & 0.971 & 0.027 \\
Stock trading performance & 2.154 & 0.989 & 0.992 & 0.962 & 0.019 \\
\hline
\end{tabular}

Source: Kourtidis et al. (2011)

Cross-tabulation and Correlation analyses reveal that, demographic and socioeconomic factors are associated with overconfidence. More specifically, high income and high educational level have a statistically significant association with the level of overconfidence (Table 6). In spite of the fact that some studies have supported a negative relationship between experience and overconfidence (Ekholm and Pasternack, 2008; Gervais and Odean, 2001; Locke and Mann, 2001; Menkhoff et al., 2006, Christoffersen and Sarkissian, 2002), analysis has shown that investment experience is positively correlated with overconfidence). In the same line, the majority of the studies have found similar findings (Frascara, 1999; Kirchler and Maciejovsky, 2002; Glaser et al., 2003; Griffin and Tversky, 1992; Obernarcher and Osler, 2008; Chen et al., 2004).

Cross-tabulation analysis also reveals that men are more overconfident than women and confirms the fifth association (with a statistically significant relationship) (Table 6). In spite of the fact that some studies have found that no difference in overconfidence exist between men and women (Lundeberg et al., 2000; Deaves et al., 2003; Biais et al., 2005), the main volume of literature suggests that men are apparently more predisposed to overconfidence than women (Lundeberg et al., 1994; Hair et al., 1998; Barber and Odean, 2000, 2001; Niederle and Vesterlund, 2007; Hair et al., 1998).

\subsection{Profile analysis-biases and demographics}

As it was expected, overconfident investors have significantly higher degree of Overconfidence (mean 27.98) than Underconfident investors (mean 19.51). Similarly, with other findings (Lundeberg et al., 1994; Barber and Odean, 2000, 2001) that men are apparently more predisposed to overconfidence than women (Table 4), it is found that the overconfident investors' cluster include more men (91\%) than women. Although a similar picture appears looking at underconfident investors' cluster, men are $75 \%$ while women are $25 \%$. Further, the majority of the investors in the sample are young $(62 \%$ of them are $<45$ years old), and do not differ much, as far as this characteristic, within the two groups. Moreover, overconfident investors have a better educational level $(79 \%$ hold at least a University degree) than Underconfident investors (only 15\% of them hold a Master degree, while $35 \%$ of them are high-school graduated). Finally, overconfident investors earn higher income (58 percent of them earn more than 30,000 Euros annually) than Underconfident investors (only 40\% earn more than 30,000 Euros annually). 


\subsection{Profile analysis-trading behaviour}

Overconfident investors' cluster is consisted of both professional (48\%) and individual $(52 \%)$ investors. On the other hand, underconfident investors' cluster consists mainly of individual investors $(85 \%)$. This is not surprising since there are findings indicating that professionals are more overconfident than individuals (Glaser et al., 2005; Putz and Ruenzi, 2008). Since the cluster with the higher number of professionals is this of overconfident investors, then it is also expected that overconfident investors will have more years of investment experience. This is indeed supported from the findings of this research (confirming the fourth association), since $67 \%$ of them have more than 10 years of investment experience, while only $30 \%$ of the overconfident investors have more than 10 years of investment experience. This is also in line with the findings of previous researches where a positive association between investment experience and overconfidence is found (Frascara, 1999; Maciejovsky and Kirchler, 2003; Glaser et al., 2003; Griffin and Tversky, 1992; Obernarcher and Osler, 2008).

Most of the investors from both clusters prefer long-term investments, followed by medium-term investments. A small percentage only, prefers the short-term investments. Amazingly, regarding the investment strategy, both group of investors seem to prefer the 'wait and see' policy (53\% and 70\% of the overconfident and underconfident investors, respectively).

What was probably not expected is the high percentage $(49 \%)$ of overconfident investors who insist on buying stocks with poor performance, while only $34 \%$ of underconfident investors exhibit similar behaviour. A possible explanation for this is that overconfident investors probably are more optimistic and they rarely abandon their hopes that their choices would be justified. Another, statistically significant difference between these two groups is that overconfident investors rely more heavily on fundamental, technical analysis and balance sheets, than underconfident investors, who rely more on other information sources, such as Newspapers and TV news. However, this is reasonable, since as it is presented earlier, the OI cluster consists of both individual and professional investors, while UI cluster consists mainly of individual investors.

As far as the stock trading behaviour (Table 6) is concerned, most $(80 \%)$ of the overconfident investors check stock prices daily, while underconfident investors check prices with significantly lower frequency (only $41 \%$ of them check prices daily). Similar to other researchers' findings (Glaser and Weber, 2007; Grinblatt and Keloharju, 2009; Deaves et al., 2003) who have found that overconfident investors trade (Table 6) more often, it is found that overconfident investors trade significantly more often $(30 \%$ of them make stock transactions at least weekly) than underconfident investors ( $9 \%$ make stock transactions weekly and $60 \%$ of them make stock transactions semi-annually) confirming the second association.

Examining the differences among the two groups of investors, as far as portfolio value, stock volume, stock returns, and profitable stock transactions are concerned (Table 5), it is found that overconfident investors' portfolio value is significantly higher (102,254 Euros on average) than that of Underconfident investors (32,311 Euros on average). Association one is confirmed, showing that overconfident investors have significantly higher stock volume (11,216 Euros per transaction) compared with underconfident investors (6318 Euros per transaction), which is in line with the findings of Glaser and Weber (2007), De Bondt and Thaler (1995), Dow and Gorton (1997), Odean (1998a, 1998b, 1999), Gervais and Odean (2001). 
Further, looking at the third association, as well as at other researchers' findings (De Long et al., 1990; Wang, 2001; Grinblatt and Keloharju, 2009; Glaser and Weber, 2007; Gervais and Odean, 2001), overconfident investors' stock returns are significantly greater $(17.81 \%)$ than what underconfident investors achieve $(8.08 \%)$ and, also, overconfident investors reports significantly more profitable stock transactions than the underconfident investors (59.58\% and $51.47 \%$, respectively).

\subsection{Results -cluster analysis}

Cluster analysis identified two investor profiles, the Overconfident and Underconfident investor profile, with each one of them exhibiting different trading behaviour. The results of the analyses show that the higher the level of investors' overconfidence, the higher the stock trading performance of these investors. Therefore, high overconfidence seems to be positively associated with stock returns (overconfident investors' profile results). These investors own portfolios with higher value, trade higher volumes of stocks and make transactions more often compared with the investors with other profile. Probably overconfidence induces people to invest, increasing their willingness to invest and, as a result, increasing trading frequency, undertaking more risk, and occasionally earning more profits.

On the other hand, underconfident investors underperform in stock markets, trade rarely and their major characteristics, compared with other investors, are the low scores of overconfidence bias.

Overconfident investors' trading behaviour may be explained by their high level of overconfidence (similar with Biais et al.'s, 2005; Grinblatt and Keloharju's, 2009; Durand et al.'s, 2008; Dorn and Huberman's, 2005 findings), but also may be explained by the large proportion of professional investors (similar with Sharma's et al., 2006; Shapira and Venezia's, 2001 findings), included in this group. Additionally, the comparison between professional and individual investors has provided evidence that professionals have better stock performance than individual investors. Professional investors' trading behaviour may be explained by the large investment experience they have (Sharma et al., 2006; Shapira and Venezia, 2001).

Furthermore, there is a statistically significant and positive relationship between overconfidence and portfolio value (Glaser and Weber, 2007; Dow and Gorton, 1997). A logical explanation may be that overconfident people think and act in a more optimistic way and, therefore, it is rather expected to buy more stocks. Additionally, our findings show that higher value portfolios lead to higher trading volume, which is in line with Glaser et al. (2003) and, also, that there is a statistically significant association between higher value portfolios and higher performance. In addition, similar to Statman and Thorely's (1999) findings, we argue that high stock returns are correlated with high trading volume. Thus, high trading frequency and high stock volume do not negatively affect investment performance but may lead, under specific conditions, to a better performance.

\section{Confirmatory factor analysis}

In spite of the fact that cluster analysis provides useful information about investors' trading profiles, it does not provide clear indications about possible causal relationships 
between the parameters examined. This has been done performing a specific multivariate statistical analysis (structural equation modelling-SEM). First, CFA (confirmatory factor analysis) was carried out using AMOS, to obtain additional information on the validity of the research instrument. The results of this test indicate a good model fit (Table 6), confirming the validity of variables used (overconfidence, stock trading performance, stock trading volume and stock trading frequency).

The results indicate that the proposed model show a sufficient explanatory power (Figure 1). More specifically, the effects of the exogenous constructs account for $23 \%$ of the variance in stock trading performance, $19 \%$ of the variance in stock trading frequency and $17 \%$ of the variance in stock trading volume.

The weights of each of the constructs in the endogenous construct are the following (Table 8): Overconfidence has a direct effect on stock trading performance $(r=0.41)$, on stock trading volume $(0.34)$ and on stock trading frequency $(0.36)$.

Figure 1 Model (see online version for colours)

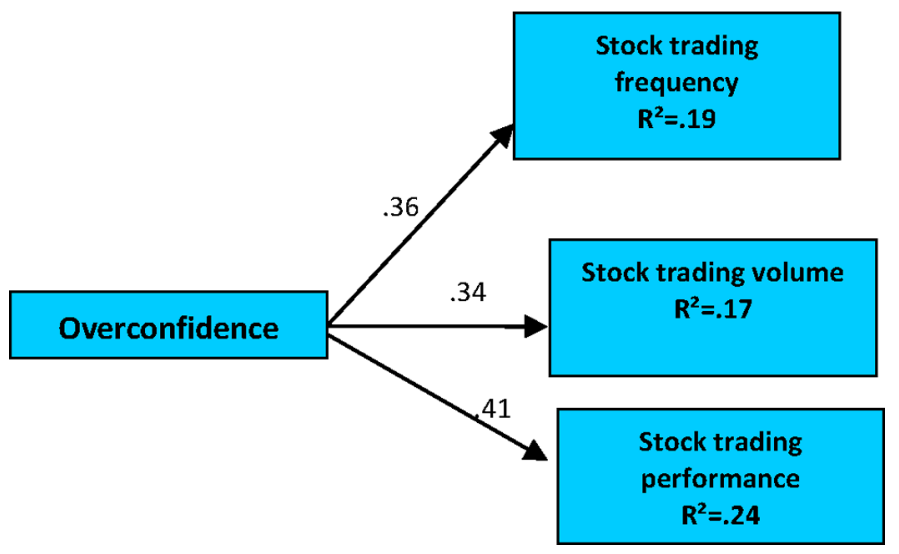

Table 8 Association testing

\begin{tabular}{lllll}
\hline No. & \multicolumn{3}{l}{ Relationships } & \\
\hline 1 & H1 & Overconfidence $\rightarrow$ Stock trading volume & $0.34^{* * *}$ & Accepted \\
2 & H2 & Overconfidence $\rightarrow$ Stock trading frequency & $0.36^{* * *}$ & Accepted \\
3 & H3 & Overconfidence $\rightarrow$ Stock trading performance & $0.41^{* * *}$ & Accepted \\
\hline
\end{tabular}

$* * p<0.05$ level; $* * p<0.01$ level.

\subsection{Results structural equation modelling analysis}

Association one is accepted, because a statistically significant positive relationship is found between overconfidence and stock trading volume (similar to the findings of Dow and Gorton, 1997). For example, Glaser and Weber (2007), supported the claim that the higher the level of investors' overconfidence, the higher their trading volume. Additionally, Deaves et al. (2003) performing an experiment on overconfidence and trading activity, have found that overconfidence increases trading volume. Moreover, Statman et al. (2006) argue that trading volume will be higher as investment success increases the degree of overconfidence. 
Additionally, Association two, which assumes that overconfidence positively influences stock trading frequency, is also accepted (statistically significant positive relationship). This relationship is in line with the findings of Alemanni and Franzosi's (2006), Grinblatt and Keloharju's (2009) and Glaser and Weber's (2007) research. Further Association three is also accepted, as overconfidence is the strongest predictor of stock trading performance in the model. There are other studies which underline this positive relationship, such as De Long et al. (1990) and Wang (2001), who have found that overconfident investors earn higher returns than less confident investors. Therefore, when investors have confidence in their own investment abilities, this does not necessarily mean that they should have a false overconfidence. This confidence can be derived from knowledge or information about the stock market. On the other hand, there are studies with opposite findings, thus, that overconfidence is associated with lower returns (Philip, 2007; Barber and Odean, 2001; Odean, 1998b; Daniel et al., 1998). The results from testing the model have shown that overconfidence bias improve stock trading performance.

\section{Conclusions}

According to cluster analysis an investor who has high level of overconfidence seems to perform better than an investor who has low confidence. Therefore, investors should have confidence in their own investment abilities, but this does not mean that they should have a fake overconfidence. This confidence can be derived from knowledge or information about stock market, investments and economy in general. For example, professionals' high scores on overconfidence is a result of their knowledge, information or experience about investments and the stock market. This association could indicate an indirect positive relationship between knowledge, information, investment experience and stock trading performance.

Moreover, SEM analysis confirms the association between Overconfidence and Trading Behaviour indicating that there is a positive relationship between Overconfidence and stock performance, as well as stock frequency and stock volume.

The paper suggests an investor profile (with specific characteristics) that induces an improved stock performance. For example, an overconfident investor would have better performance than an investor who is underconfident. Therefore, individual and professional investors may be able to follow a more profitable strategy. Moreover, this study, in spite of the fact that it was conducted on the Greek market, can help people understand what happens in investors' behaviour in other similar (small) capital markets in all over the world.

This is an exploratory study to be used as a starting point for the understanding of specific characteristics of investors (including both individuals and professionals) and their trading behaviour. The results show that high level of overconfidence is associated with trading behaviour, in respect of trading performance, trading frequency and trading volume. Unfortunately, one may assume that the above characteristics lead to a winning strategy in stock markets. This study may provide investment advisors with a framework to understand clients' attitude and, thus, allow advisors to give better advice to their clients depending on each client's profile. Ultimately, it may help investors understand how biases and traits affect investment decisions and thus they may be able to become aware of and overcome them. 
One major limitation of this study is that it is based on the self-assessed biases, traits and trading behaviour of each respondent. It is important that future research could be directed towards collecting more objective data, as far as these crucial parameters are concerned.

Further research could also expand the scope of this research by examining the same issues in other countries in Europe and in the USA to compare, or to verify, these results. Moreover, it is recommended that future research could add more constructs such as 'mental accounting' (Goldberg and Von Nitsch, 2001; Goetzmann and Massa, 2003) and 'disposition effect' (Nofsinger, 2007; Chang, 2008; Statman et al., 2006; Dhar and Zhu, 2006; Brown et al., 2006) to generate a model.

\section{References}

Alemanni, B. and Franzosi, A. (2006) Portfolio and Psychology of High Frequency Online Traders, Working Paper, University of Genoa Borsa Italiana Spa, Genoa.

Barber, B. and Odean, T. (2000) 'Trading is hazardous to your wealth: the common stock investment performance of individual investors', Journal of Finance, Vol. 55, No. 2, pp.773-806.

Barber, B. and Odean, T. (2001) 'Boys will be boys: gender overconfidence, and common stock investment', Quarterly Journal of Economics, Vol. 116, No. 1, pp.261-292.

Barber, B. and Odean, T. (2002) 'Online investors: Do the slow die first?', Review of Financial Studies, Vol. 15, No. 1, pp.455-487.

Barberis, N. and Thaler, R. (2003) 'A survey of behavioural finance'. in Constantinidis, G.M., Harris, M. and Stulz, R.M. (Eds.): Handbook of the Economics of Finance, Vol. 1B, Elsevier, Amsterdam, pp.1053-1123.

Barberis, N. and Thaler, R. (2005) 'A survey of behavioural finance', in Thaler, R.H. (Ed.): Advances in Behavioural Finance, Vol. 2, No. 1, pp.1-75.

Bazerman, M. (1998) Judgment in Managerial Decision-Making, John Wiley and Sons, New York.

Ben-David, I., Graham, J. and Harvey, C.R. (2007) Managerial Overconfidence and Corporate Policies, Working Paper, Duke University.

Bhandari, G. and Deaves, R. (2006) 'The demographics of overconfidence', Journal of Behavioural Finance, Vol. 7, No. 1, pp.5-11.

Biais, B., Hilton, D., Mazurier, K. and Pouget, S. (2005) 'Judgmental overconfidence, selfmonitoring and trading performance in an experimental financial market', Review of Economic Studies, Vol. 72, No. 2, pp.287-312.

Brown, P.N., Chappel, R., Da Silva, R. and Walter, T. (2006) 'The reach of the disposition effect: large sample evidence across investor classes', International Review of Finance, Vol. 6, Nos. 1-2, pp.43-78.

Byrne, A. and Brooks, M. (2008) 'Behavioural finance: theories and evidence', The Research Foundation of CFA Institute Literature Review, Vol. 3, No. 1, pp.1-25.

Caballe, J. and Sakovics, J. (2003) 'Speculating against an overconfident market', Journal of Financial Markets, Vol. 6, No. 2, pp.199-225.

Campbell, W.K., Goodie, A.S. and Foster, J.D. (2004) 'Narcissism, confidence, and risk attitude', Journal of Behavioural Decision Making, Vol. 17, No. 4, pp.297-311.

Chang, C. (2008) 'The impact of behavioural pitfalls on investors' decisions: the disposition effect in the taiwanese warrant market', Social Behaviour and Personality, Vol. 36, No. 5, pp.617-634. 
Chen, G., Kim, K. and Nofsinger, J. (2004) Behaviour and Performance of Emerging Market Investors: Evidence from China, Working Paper, Hong Kong Polytechnic University, Hong Kong.

Cheng, P.Y.K. (2007) 'The trader interaction effect on the impact of overconfidence on trading performance: an empirical study', Journal of Behavioural Finance, Vol. 8, No. 2, pp.59-69.

Christoffersen, S. and Sarkissian, S. (2002) Location Overconfidence, Working Paper, McGill University.

Chuang, W.I. and Lee, B.S. (2006) 'An empirical evaluation of the overconfidence hypothesis', Journal of Banking and Finance, Vol. 30, No. 9, pp.2489-2515.

Cummins, R.A. and Lau, A.L.D. (2005) Personal Wellbeing Index - School. Children, 3rd ed., PWI-PS (Chinese-Cantonese).

Daniel, K. Hirshleifer, D. and Subrahmanyam, A. (1998) 'Investor psychology and security market under and overreactions', Journal of Finance, Vol. 53, No. 6, pp.1839-1885.

Daniel, K. Hirshleifer, D. and Subrahmanyam, A. (2001) 'Overconfidence, arbitrage, and equilibrium asset pricing', Journal of Finance, Vol. 56, No. 3, pp.921-965.

De Bondt, W. and Thaler, R.H. (1995) 'Financial decision-making in markets and firms: a behavioural perspective', in Jarrow, R.A., Maksimovic, V. and Ziemba, W.T. (Eds.): Finance Handbooks in Operations Research and Management Science, North Holland, Amsterdam, pp.385-410.

De Long, J.B., Schleifer, A., Summers, L.H. and Waldmann, R.J. (1990) 'Noise trader risk in financial markets', Journal of Political Economy, Vol. 98, No. 4, pp.703-738.

Deaves, R., Lüders, E. and Luo, G.Y. (2003) An Experimental Test of Over-confidence and Gender on Trading Activity, Working paper, McMaster University, Ontario.

DeLamater, J.D. and Myers, D.J. (2011) Social Psychology, 7th ed., Wadsworth, Belmont, CA.

DellaVigna, S. (2009) 'Psychology and economics: evidence from the field', Journal of Economic Literature, Vol. 47, No. 2, pp.315-372.

Dhar, R. and Zhu, N. (2006) 'Up close and personal: a cross-sectional study of the disposition effect', Management Science, Vol. 52, No. 5, pp.726-740.

Dorn, D. and Huberman, G. (2005) 'Talk and action: What individual investors say and what they do?', Review of Finance, Vol. 9, No. 4, pp.1-45.

Dow, J. and Gorton, G. (1997) 'Noise trading, delegated portfolio management and economic welfare', Journal of Political Economy, Vol. 105, No. 1, pp.1024-1050.

Durand, R., Newby, R. and Sanghani, J. (2008) 'An intimate portrait of the individual investor', Journal of Behavioural Finance, Vol. 9, No. 4, pp.193-208.

Ekholm, A. and Pasternack, D. (2008) 'Overconfidence and investor size', European Financial Management, Vol. 14, No. 1, pp.82-98.

Fabre, B. and Francois-Heude, A. (2009) 'Optimism and overconfidence investors' biases: a methodological note', Finance, Vol. 30, No. 1, pp.79-119.

Fama, E.F. and Kenneth, F.R. (2004) 'The capital asset pricing model: theory and evidence', Journal of Economic Perspectives, Vol. 18, No. 3, pp.25-46.

Fenton-O'Creevy, M., Nicholson, N., Soane, E. and Willman, P. (2003) 'Trading on illusions: unrealistic perceptions of control and trading performance', Journal of Occupational and Organizational Psychology, Vol. 76, No. 1, pp.53-68.

Firat, D. and Fettahoglou, S. (2011) "Investors' purchasing behaviour via a behavioural finance approach', International Journal of Business and Management, Vol. 6, No. 7, pp.153-163.

Flynn, F.J. and Ames, D.R. (2006) 'What's good for the goose may not be as good for the gander: the benefits of self-monitoring for men and women in task groups' and dyadic conflicts', Journal of Applied Psychology, Vol. 91, No. 2, pp.272-281. 
Frascara, J. (1999) 'Cognition, emotion and other inescapable dimensions of human experience', Visible Language, Vol. 33, No. 1, pp.74-87.

Garvey, R. and Murphy, A. (2004) 'Are professional traders too slow to realize their losses', Financial Analysts Journal, Vol. 60, No. 1, pp.35-43.

Geisinger, G.F. (2003) 'Testing and assessment in cross-cultural psychology', in Graham, J.R., Naglieri, J.A. and Weiner, I.B. (Eds.): Handbook of Psychology, Vol. 10, Assessment Psychology, John Wiley and Sons, Hoboken, pp.95-118.

Gervais, S. and Odean, T. (2001) 'Learning to be overconfident', Review of Financial Studies, Vol. 14, No. 1, pp.1-27.

Glaser, M. and Weber, M. (2005) 'September 11 and stock return expectations of individual investors', Review of Finance, Vol. 9, No. 2, pp.243-279.

Glaser, M. and Weber, M. (2007) 'Overconfidence and trading volume', Geneva Risk Ins Rev., Vol. 32, No. 1, pp.1-36.

Glaser, M. and Weber, M. (2010) 'Overconfidence', in Baker, H.K. and Nofsinger, J. (Eds.): Behavioral Finance: Investors, Corporations, and Markets, John Wiley \& Sons, Inc., Hoboken, NJ, pp.241-258.

Glaser, M., Langer, T. and Weber, M. (2003) 'On the trend recognition and forecasting ability of professional traders', Decision Analysis, Vol. 4, No. 4, pp.176-193.

Glaser, M., Langer, T. and Weber, M. (2013) 'True overconfidence in interval estimates: evidence based on a new measure of miscalibration', Journal of Behavioral Decision Making, Vol. 26, No. 5, pp.405-417.

Goetzmann, W.N. and Massa, M. (2003) Disposition Matters: Volume, Volatility and Price Impact of a Behavioral Bias, NBER Working Paper No. 9499

Goldberg, J. and Von Nitsch, R. (2001) Behavioural Finance, John Wiley and Sons Ltd, Chichester.

Graham, J., Harvey, C. and Huang, H. (2009) 'Investor competence, trading frequency, and home bias', Management Science, Vol. 55, No. 7, pp.1094-1106.

Griffin, D. and Tversky, A. (1992) 'The weighting of evidence and the determinants of confidence', Cognitive Psychology, Vol. 3, No. 3, pp.430-454.

Grinblatt, M. and Keloharju, M. (2009) 'Sensation seeking overconfidence and trading activity', The Journal of Finance, Vol. 2, No. 4, pp.549-578.

Hair, J.F., Anderson, J.R., Tatham, R.E. and Black, W.C. (1998) Multivariate Data Analysis, 5th ed., Prentice Hall, Upper Saddle River, NJ.

Hair, J.F., Anderson, R.E., Tatham, R.L. and Black, W.C. (1989) Multivariate Data Analysis with Readings, 5th ed., Prentice-Hall, Upper Saddle River, NJ.

Hatcher, L. (1994) A Step-by-Step Approach to Using the SAS System for Factor Analysis and Structural Equation Modelling, The SAS Institute, Cary, NC.

Hilton, D. (2001) 'Psychology and the financial markets: applications to trading, dealing and investment analysis', Psychology and the Financial Markets, Vol. 2, No. 1, pp.37-53.

Hilton, L., Régner, I., Cabantous, D., Charalambides, L. and Vautier, S. (2011) 'Do positive illusions predict overconfidence in judgment? A test using interval production and probability evaluation measures of miscalibration', Journal of Behavioral Decision Making, Vol. 24, pp.117-139.

Hirshleifer, D. and Luo, G.Y. (2001) 'On the survival of overconfident traders in a competitive securities market', Journal of Financial Markets, Vol. 4, No. 1, pp.73-84.

Hogarth, R.M. (1987) Judgment and Choice: The Psychology of Decision, John Wiley and Sons, New York.

Johnson, D.D.P. and Fowler, J.H. (2009) 'The evolution of overconfidence', Nature, Vol. 477, pp.317-320. 
Kahneman, D. and Riepe, M.W. (1998) 'Aspects of investor psychology', Journal of Portfolio Management, Vol. 24, No. 1, pp.52-65.

Kahneman, D. and Tversky, A. (1979) 'Prospect theory: an analysis of decision under risk', Econometrica, Vol. 47, No. 2, pp.263-291.

Keller, C. and Siergist, M. (2006) 'Investing in stocks: the influence of financial risk attitude and values-related money and stock market attitudes', Journal of Economic Psychology, Vol. 27, No. 2, pp.285-303.

Kim, K.A. and Nofsinger, J.R. (2007) 'The behaviour of Japanese individual investors during bull and bear markets', Journal of Behavioural Finance, Vol. 8, No. 3, pp.138-153.

Kirchler, E. and Maciejovsky, B. (2002) 'Simultaneous over- and under-confidence: evidence', The Journal of Risk and Uncertainty, Vol. 25, No. 1, pp.65-85.

Kiyilar, M. and Acar, O. (2009) 'Behavioural finance and the study of the irrational financial choices of credit card users', Annales Universitatis Apulensis Series Oeconomica, Vol. 11, No. 1, pp.457-468.

Kourtidis, D., Sevic, Z. and Chatzoglou, P. (2011) 'Investors' trading activity, a behavioural perspective and empirical results', Journal of socio-economics, Vol. 40, No. 5, pp.548-557.

Kruger, J. (1999) 'Lake Wobegon be gone! The 'below-average effect' and the egocentric nature of comparative ability judgments', Journal of Personality and Social Psychology, Vol. 77, No. 2, pp.221-232.

Larrick, R.P., Burson, K.A. and Soll, J.B. (2007) 'Social comparison and confidence: when thinking you're better than average predicts overconfidence (and when it does not)', Organizational Behavior and Human Decision Processes, Vol. 102, pp.76-94.

Lichtenstein, S., Fischhoff, B. and Phillips, L. (1982) 'Calibration of probabilities: the state of the art to 1980', in Kahneman, D., Slovic, P. and Tversky, A. (Eds.): Judgment under Uncertainty: Heuristics and Biases, Cambridge University Press, Cambridge, UK, New York, pp.306-334.

Linnainmaa, J. (2011) 'Why do (some) households trade so much?', Review of Financial Studies, Vol. 24, No. 5, pp.1630-1666.

Lo, A.W. and MacKinley, C.A. (1999) A Non-Random Walk Down Wall Street, Princeton University Press, Princeton.

Locke, P.R. and Mann, S.C. (2001) House Money and Overconfidence on the Trading Floor, Working Paper, George Washington University.

Lundeberg, M., Fox, P. and Puncochar, J. (1994) 'Highly confident but wrong: gender differences and similarities in confidence judgments', Journal of Educational Psychology, Vol. 86, No. 1, pp.114-121.

Lundeberg, M., Fox, P., Brown, A. and Elbedour, S. (2000) 'Cultural influences on confidence: country and gender', Journal of Educational Psychology, Vol. 92, No. 1, pp.152-159.

Maciejovsky, B. and Kirchler, E. (2003) 'Simultaneous over- and underconfidence: evidence from experimental asset markets', Journal of Risk and Uncertainty, Vol. 25, No. 1, pp.65-85.

Marković, S. and Raspor, S. (2010) 'Measuring perceived service quality using SERVQUAL: A case study of the creation hotel industry', Management, Vol. 5, No. 3, pp.195-209.

Markowitz, H.M. (1952) 'Portfolio selection', Journal of Finance, Vol. 7, No. 1, pp.77-91.

Menkhoff, L., Schmidt, U. and Brozynski, T. (2006) 'The impact of experience on risk taking, overconfidence, and herding of fund managers: complementary survey evidence', European Economic Review, Vol. 50, No. 7, pp.1753-1766.

Nagy, R.A. and Obenberger, R.W. (1994) 'Factors influencing investor behaviour', Financial Analysts Journal, Vol. 50, No. 1, pp.63-68.

Niederle, M. and Vesterlund, L. (2007) 'Do women shy away from competition? Do men compete too much?', Quarterly Journal of Economics, Vol. 122, No. 3, pp.1067-1101. 
Nofsinger, J.R. (2007) The Psychology of Investing, 3rd ed., Prentice Hall, New York.

Obernarcher, T. and Osler, C.L. (2008) Overconfidence in Currency Markets, Working Paper, Harvard University, Harvard Kennedy School, Harvard.

Odean, T. (1998a) 'Are investors reluctant to realize their losses?', Journal of Finance, Vol. 53, No. 5, pp.1775-1798.

Odean, T. (1998b) 'Volume, volatility, price and profit when all traders are above average', Journal of Finance, Vol. 53, No. 6, pp.1887-1934.

Odean, T. (1999) 'Do investors trade too much?', American Economic Review, Vol. 89, No. 5, pp.1279-1298.

Philip, C. (2007) 'The trader interaction effect on the impact of overconfidence on trading performance: an empirical study', The Journal of Behavioural Finance, Vol. 8, No. 2, pp.59-69.

Pompian, M.M. (2006) Behavioural Finance and Wealth Management, John Wiley and Sons Inc., New Jersey.

Presson, P.K. and Benassi, V.A. (1996) 'Illusion of control: a meta-analytic review', Journal of Social Behavior and Personality, Vol. 11, pp.493-510.

Prosad, J., Kapoor, S. and Sengupta, J. (2013) 'Impact of overconfidence and the disposition effect on trading volume', An Empirical Investigation of Indian Equity Market, Vol. 3, No. 4, pp.109-116.

Putz, A. and Ruenzi, S. (2008) Overconfidence among Professional Investors: Evidence from Mutual Fund Managers, CFR-Working Paper, University of Cologne, Cologne.

Rawls, J. (1971) A Theory of Justice, Harvard University Press, Cambridge, MA.

Russo, E. and Shoemaker, P.J. (1991) Confident Decision Making, Piatkus, London.

Russo, J. and Schoemaker, P.J.H. (1992) 'Managing over-confidence', Sloan Management Review, Vol. 33, No. 2, pp.7-17.

Scheinkman, J.A. and Xiong, W. (2003) 'Overconfidence and speculative bubbles', Journal of Political Economy, Vol. 111, No. 6, pp.1183-1219.

Shapira, Z. and Venezia, I. (2001) 'Patterns of behaviour of professionally managed and independent investors', Journal of Banking and Finance, Vol. 25, No. 8, pp.1573-1587.

Sharma, V., Easterwood, J.C. and Kumar, R. (2006) Institutional Herding and Internet Bubble, Working Paper, Ann Arbor: University of Michigan.

Shefrin, H.H. (2002) Beyond Greed and Fear. Understanding Behavioural Finance and the Psychology of Investing, Oxford University Press, New York.

Shiller, R. (2000) Irrational Exuberance, Princeton University Press, Princeton.

Shiller, R.J. (2002) From Efficient Market theory to Behavioural Finance, Cowles Foundation Discussion Papers No. 1385, New Haven: Yale University.

Shive, S. (2010) 'An epidemic model of investor behaviour', Journal of Financial and Quantitative Analysis, Vol. 45, No. 1, PP.169-198.

Shu, P., Chiu, S., Chen, H. and Yeh, Y. (2004) 'Does trading improve individual investor performance?', Review of Quantitative Finance and Accounting, Vol. 22, No. 3, pp.199-217.

Siegel, J. (2007) Stocks for the Long Run: The Definitive Guide to Financial Market Returns and Long-Term Investment Strategies, 4th ed., McGraw-Hill, New York.

Siwal, E. (2011) 'The impact of overconfidence bias and disposition effect on the volume of transaction and the volatility of the French stock market', The Journal of Applied Economic Sciences, Vol. 6, No. 1, pp.61-83.

Statman, M. and Thorley, S. (1999) Overconfidence, Disposition and Trading Volume, Working Paper, Santa Clara University, Santa Clara. 
Statman, M., Thorley, S. and Vorkink, K. (2006) 'Investor overconfidence and trading volume', Review of Financial Studies, Vol. 19, No. 4, pp.1531-1565.

Svenson, O. (1981) 'Are we all less risky and more skillful than our fellow drivers?', Acta Psychologica, Vol. 47, pp.143-148.

Takahashi, H. and Terano, T. (2003) 'Agent-based Approach to investor's behavior and asset price fluctuation in financial markets', Journal of Artificial Societies and Social Simulation, Vol. 6, No. 3, pp.159-173.

Taylor, S.E. and Brown, J.D. (1988) 'Illusion and well-being: a social psychological perspective on mental health', Psychological Bulletin, Vol. 103, No. 2, pp.193-210.

Teigen, K.H. and Jørgensen, M. (2005) 'When 90\% confidence intervals are 50\% certain: on the credibility of credible intervals', Applied Cognitive Psychology, Vol. 19, pp.455-475.

Tourani-Rad, A. and Kirkby, S. (2005) 'Investigation of investor's overconfidence familiarity and socialisation', Accounting and Finance, Vol. 45, No. 2, pp.283-300.

Trinugroho, I. and Sembel, R. (2011) 'Overconfidence and excessive trading behaviour: an experimental study', International Journal of Business and Management, Vol. 6, No. 7, pp.147-152.

Tyynela, M. and Perttunen, J. (2003) 'Trading behaviour of Finnish households: activity, performance and overconfidence', Finnish Journal of Business Economics, Vol. 52, No. 3, pp.157-178.

Wang, F.A. (2001) 'Overconfidence, investor sentiment, and evolution', Journal of Financial Intermediation, Vol. 10, No. 2, pp.138-170.

Weinstein, N. (1980) 'Unrealistic optimism about future life events', Journal of Personality and Social Psychology, Vol. 39, No. 5, pp.806-820.

Wood, R. and Zaichkowsky, J.L. (2004) 'The institute of psychology and markets attitudes and trading behaviour of stock market investors: a segmentation approach', The Journal of Behavioural Finance, Vol. 5, No. 3, pp170-179.

Zikmund, W.G. (2003) Business Research Methods, 7th ed., Thomson/South-Western, Mason.

Hoelzl, E. and Rustichini, A. (2005) 'Overconfident: Do you put your money on it?', Economic Journal, Vol. 115, No. 503, pp.305-318.

\section{Appendix: Questionnaire}

\section{A. DEMOGRAPHICS}

The following questions refer to your demographic characteristics (Please tick the options that better represent you, and fill the spaces)

\begin{tabular}{|c|c|c|c|}
\hline A. 1 & Gender & Man & Woman \\
\hline \multirow[t]{3}{*}{ A. 2} & Family situation & Single & Widow \\
\hline & & Married & Cohabitation \\
\hline & & Divorced & \\
\hline \multirow[t]{3}{*}{ A. 3} & Please choose the group that best describes & $25-35$ years old & $56-65$ years old \\
\hline & your age & 36-45 years old & $>65$ years old \\
\hline & & $46-55$ years old & \\
\hline A. 4 & $\begin{array}{l}\text { How many members of your family (who are } \\
\text { financially supported by you) belong to the } \\
\text { following categories? (put a number between } \\
\text { each bracket) }\end{array}$ & $\begin{array}{l}\text { Children ... } \\
\text { University student... }\end{array}$ & > Elderly... \\
\hline
\end{tabular}


Overconfidence and stock returns: a behavioural perspective

\section{Appendix: Questionnaire (continued)}

B. SOCIOECONOMIC

The following questions refer to your socioeconomic characteristics (Please tick the options that better describe your current status)

B.1 Which Educational level have you completed?

B.2 What was the subject of your studies? (You can choose more than one answer)

B.3 Please specify which of the following options better describes your current occupation.

B.4 Please name the industry the organisation you work for belongs in

B.5 Please define your position in this organisation

B.6 Please specify the appropriate level closer to your family annual income

B.7 If you have a loan/mortgage please state the type of the loan

B.8 How many times your family's monthly income is your loan/mortgage?

$\begin{array}{ll}\text { High-school } & \text { Master } \\ \text { University } & \mathrm{PhD} \\ \text { Management } & \text { Medicine } \\ \text { Economics/Finance } & \text { Law } \\ \text { Math } & \text { Engineering } \\ \text { Information systems } & \text { Other, specify... } \\ \text { Private Sect. employee } & \text { Retired } \\ \text { Public Sect. employee } & \text { Unemployed } \\ \text { Self-Employed } & \text { Other, specify... } \\ \text { Business owner } & \end{array}$

Please specify

Please specify. $€ 50,001-€ 100,000$

$>€ 100,000$

$€ 15,001-€ 30,000$

Business

$€ 30,001-€ 50,000$

Other, specify...

Mortgage

Retail

Please specify...

C. STOCK TRANSACTIONS

The following questions refer to some of your trading characteristics (Please tick the options that better represents you, and fill the spaces)

\begin{tabular}{|c|c|c|c|}
\hline C.1 & $\begin{array}{l}\text { How long have you been investing (in stocks or } \\
\text { bonds)? }\end{array}$ & Less than 5 years & More than 10 years \\
\hline & & $5-10$ years & \\
\hline C. 2 & What percentage of your total portfolio are & Saving accounts.....\% & Stocks............\% \\
\hline & invested in: (You can tick more than one option) & Mutual Funds........\% & Real Estate.......\% \\
\hline & & Bonds.......\% & $\begin{array}{l}\text { Other, } \\
\text { specify....... }\end{array}$ \\
\hline C. 3 & $\begin{array}{l}\text { How your investments are distributed within } \\
\text { different investment horizons (\% of your }\end{array}$ & $\begin{array}{l}\text { Long term }(>1 \text { year }) \text { in } \\
\text { horizon...........\% }\end{array}$ & nvestment \\
\hline & portfolio that belongs in each time horizon)? & $\begin{array}{l}\text { Medium term }(3-12 \mathrm{~m} \\
\text { horizon......\% }\end{array}$ & honths) investm. \\
\hline & & $\begin{array}{l}\text { Short term }(<3 \text { months }) \\
\text { horizon..........\% }\end{array}$ & ) investm. \\
\hline
\end{tabular}




\section{Appendix: Questionnaire (continued)}

C. STOCK TRANSACTIONS

The following questions refer to some of your trading characteristics (Please tick the options that better represents you, and fill the spaces)

\begin{tabular}{|c|c|c|c|}
\hline \multirow[t]{2}{*}{ C. 4} & \multirow{2}{*}{$\begin{array}{l}\text { What stocks does your portfolio consist of? } \\
\text { (state \% of the stocks from each group) }\end{array}$} & ASE $20: \ldots \ldots \ldots \%$ & ASE $80: \ldots \ldots . . . .0$ \\
\hline & & ASE $40: \ldots \ldots . . . . \%$ & Other, specify.. \\
\hline C.5 & $\begin{array}{l}\text { What is approximately the current value of your } \\
\text { portfolio? }\end{array}$ & Please specify...€ & \\
\hline \multirow[t]{4}{*}{ C.6 } & How frequently do you buy or sell stocks? & Daily & Quarterly \\
\hline & & Weekly & Semi-annually \\
\hline & & Fortnightly & Yearly \\
\hline & & Monthly & \\
\hline
\end{tabular}

C.7 What is an average value of a transaction you complete?

Please specify

C.8 What is the usual investment policy that you follow? (You can tick more than one option)

A stop loss policy 'Wait and see'

A max profit policy Other, specify....

Target price

C.9 Could you specify your profit/loss of the stocks

Profit...\%

Loss.........\%

C.10 Could you specify the number of transactions that you have gained?

C.11 What sources of information do you usually rely on? (You can tick more than one option)

Please specify:

TV News Internet

Newspaper Financial Analysts

Balance Sheets-Inc. Friends/Relatives

St.

Fundamental Anal.- Rumours

Technical analysis

Financial Other.

Announcements

Global stock markets

C.12 Are there specific stocks that you buy despite their bad performance?

Please specify:

Please specify

C.13 If you ever make investment breaks, please specify how long they were?

C.14 If yes, what was the reason that forced you to Please specify..... stop investing in stocks?

C.15 Can you determine, what is the factor that really Please specify..... affects your investment decisions?

The following questions refer to your expectations. Rate the following questions on a degree scale of 1-5. Rate from 1 (Very positive) to 5 (Very negative)

C.16 What is your expectation about the Athens Stock Exchange?

C.17 What is your expectation about the foreign exchange markets?

C.18 Are you satisfied with your stock returns? 
Overconfidence and stock returns: a behavioural perspective

\section{Appendix: Questionnaire (continued)}

\begin{tabular}{|c|c|c|c|}
\hline \multicolumn{4}{|l|}{ D. SELF-CONFIDENCE } \\
\hline & $\begin{array}{c}I \\
\text { completely } \\
\text { disagree }\end{array}$ & $\rightarrow$ & $\begin{array}{c}I \\
\text { totally } \\
\text { agree }\end{array}$ \\
\hline & 1 & 3 & 5 \\
\hline
\end{tabular}

D.1 I am an experienced investor

D.2 I feel that on average my investment performs better than the stock market

D.3 When I purchase a winning investment, I feel that my actions and knowledge affected the result

D.4 I expect my investments to perform better than the stock market

D.5 I feel more confident in my own investment opinions over opinions of financial analysts

D.6 I feel more confident in my own investment opinions over opinions of friends and colleagues

D.7 I am likely to purchase investments that have been recommended by friends or colleagues 